JOURNAL OF SECURITY AND SUSTAINABILITY ISSUES

ISSN 2029-7017 print/ISSN 2029-7025 online

2021 Volume 11

https://doi.org/10.47459/jssi.2021.11.42

\title{
INFLUENCE OF SOCIAL PATHOLOGIES ON THE SENSE OF SECURITY OF LOCAL COMMUNITIES IN THE CONTEXT OF SUSTAINABLE DEVELOPMENT
}

\author{
Dorota Kurek $^{1}$, Marlena Niemiec ${ }^{2}$ \\ ${ }^{1,2}$ War Studies University, Management Institute, Management and Command Department, \\ al. gen. A. Chruściela „Montera” 103, 00-910 Warsaw, Poland \\ E-mails: ${ }^{1}$ d.kurek@akademia.mil.pl; ${ }^{2 m . n i e m i e c @ a k a d e m i a . m i l . p l ~}$
}

Received 18 July 2021; accepted 4 October 2021; published 20 October 2021

\begin{abstract}
The aim of the article was to determine the relationship between the occurrence of social pathologies (alcoholism, drug addiction, violence and aggression, poor financial standing, poverty, unemployment and crime) and the sense of security in local communities. The results of the research were put in the context of sustainable development. The article uses the method of diagnostic survey, with surveying as the technique and questionnaire as the tool for collecting empirical data. The survey covered 600 respondents in the following towns: Siedlce, Włocławek, Zamość, Piła, Ostrów Wielkopolski, Zgierz. The data obtained allowed to solve the research problem posed in the article and in an innovative way to demonstrate the relationship between the occurrence of basic social pathologies and their impact on the safety of the local community. The obtained results show that the respondents are aware of the occurrence of individual social pathologies in their local environment, as well as perceive their significant impact on functioning in the local community covered by the survey and have knowledge of the impact of negative phenomena on sustainable development. The article presents the author's approach to the issue of finding out about social pathologies and indicating their influence on the sense of security in the local community, as well as their importance for sustainable development.
\end{abstract}

Keywords: social pathologies, sense of security, local communities, sustainable development

Reference to this paper should be made as follows: Kurek, D., Niemiec, M. 2021. Influence of social pathologies on the sense of security of local communities in the context of sustainable development. Journal of Security and Sustainability Issues, 11, 463-479. https://doi.org/10.47459/jssi.2021.11.42

JEL classification: J60, J01, H55

\section{Introduction}

Actions aimed at the implementation of the concept of sustainable development have not only a global or regional dimension, but first and foremost a local one, which enables a direct response to social needs including the adjustment of actions to the identified scale of needs. In the assumptions of the concept of sustainable development not only the needs in the scope of ecology are emphasised, as the civilisation aspect, including socio-cultural, economic, spatial, and institutional issues, also occupies an important place. Being aware of the connection between sustainable development and the safety of local communities, the authors of this article have undertaken research aimed at showing whether and how social pathologies affect the sense of safety of local communities. The purposefulness of the undertaken actions is justified both in the aspect of the need for sustainable development and of satisfying the basic human need, which is the need for security. Since the possibility of satisfying this need in local dimension is built through a number of actions of various entities aimed at e.g. creation of equality in access to social services, goods, jobs, ensuring financial stability, elimination of the phenomenon of discrimination, urbanisation and spatial pathology limiting the possibility of efficient functioning of persons with disabilities, as well as other social pathologies such as alcoholism, drug addiction, violence, crime, suicides, devastation of environment and oppressive behaviours. 


\section{The concept of sustainable development and its pillars}

The issue of creating the conditions necessary for the harmonious development of people and nature, including such issues as peace, freedom, development, and environment (National Research Council 1999), has long been the subject of interest of various social groups - scientists, politicians, ecologists, as well as ordinary citizens. Interest in the concept of sustainability has grown over the years, as confirmed by Shi et al. (2019) citing, for example, the number of articles that appeared in various journals and publications between 2000 and 2019, while Robert et al. point to the increase in the number of non-governmental organisations (NGOs) dealing with the issue in practice (Robert et al. 2005). The extent of interest in and evolution of the concept of sustainable development can also be seen through the lens of the three periods identified in the development of the concept, such as (Shi et al. 2019: 3):

- embryonic period (before 1972),

- the moulding period (1972-1987),

- and the developing period (since 1987)".

Since the United Nations Conference on Environment and Development (UNCED) in 1992 and the creation of an agenda of 21 key actions to be taken and areas of activity confirmed 10 years later in 2002, at the World Summit on Sustainable Development in Johannesburg, South Africa (The Johannesburg Declaration on Sustainable Development 2002), the issue of sustainable development is more and more often discussed by international organisations, politicians, as well as national and local authorities, which, by increasing social awareness, undertake a number of actions aimed at the implementation of legal and social solutions enabling the creation of proper conditions for the functioning of the society and respect for the environment.

The idea of sustainable development refers to the concept of development, needs (within which the need for security is also included) and the concept of future generations (Klarin 2018). It is based on the so-called three pillars, the sustainability of which is the main objective of the measures taken (Triple bottom line concept, Klarin 2018: 68) aimed at integrating the social, environmental, and economic dimensions in a systems approach. Focusing on environmental sustainability (allowing the quality of the environment to be maintained such that activities can be carried out and the quality of life can be maintained at a certain level), linked to attention to social sustainability (manifested in respect for human rights, culture, traditions) and economic sustainability (ensuring the necessary capital to functioning), is not an easy task. It must take into account respect for the other pillars in order to maintain balance, since: "a collective responsibility to advance and strengthen the interdependent and mutually reinforcing pillars of sustainable development - economic development, social development and environmental protection - at local, national, regional and global levels" (The Johannesburg Declaration on Sustainable Development 2002:1).

Considering the above the sustainable development may be defined as "the process of increasing the spectrum of alternatives allowing individuals and communities to realize their aspirations and potential in the long perspective, at the same time maintaining the regeneration ability in economic, social, and ecological systems" (Munasinghe 1994), as well as an "ability to make development sustainable - to ensure that it meets the needs of the present without compromising the ability of future generations to meet their own needs" (WCED 1987: 8).

The implementation of the concept of sustainable development is inseparably connected with the necessity to respect key principles, which, according to Cotter and Hannan, include

- integration (decisions taken, and as a result, their effects should be considered at the social, economic, and environmental level, which requires the cooperation of authorities at the central and local level, with the involvement of local communities)

- community involvement (sustainability of progress is not possible without the involvement of the whole community, including in particular local authorities and the local community, resulting in a greater ability to monitor the effectiveness of actions); 
- preventive/precautionary behaviour (taking action to prevent environmental degradation rather than simply reacting to the effects);

- equality of different generations and equality of the generation itself (fairness and equal opportunities of representatives of different generations in access to goods);

- continuous improvement (using modern solutions to create conditions for sustainable development)

- ecological integrity (protection of the environment and biodiversity undertaken at central as well as local level) (1999:171-172).

Building a sustainable society is a great challenge, therefore, the above mentioned principles have been guiding the activities of a number of institutions and organisations of international, European, national, and local range for many years, as underlined by Robert et al, who indicates that: "The movement for sustainable livelihoods consists of local initiatives that seek to create opportunities for work and sustenance that offer sustainable and credible alternatives to current processes of development and modernization" (Robert et al. 2005: 18).

\section{Social sustainability and security}

Taking into account the need for sustainable development, it is increasingly stressed that humanity faces a number of challenges also in terms of social sustainability (Broman, Robèrt 2017). The pursuit of development while maintaining the stability of social systems requires the expansion of capacities to solve social, economic and environmental problems (Ciegis, Ramanauskiene, Martinkus 2009). The challenges are most apparent due to continued population growth (United Nations 2013), and include the need to increase the level of social trust - as there are perceived signs of declining trust in many societies (Edelman 2015), and declining social trust can directly translate into low capacity to collectively solve social problems. However, sustainable social development is not possible without sustainable economic and environmental development. Focusing attention on the issue of social sustainability, it is worth highlighting the importance of the following issues:

- improvement of living conditions and labour standards leading to job satisfaction, individual fulfilment and social development (Duran et al. 2015);

- development of social interactions, interpersonal relations, promotion of behavioural patterns and values (Dempsey et al. 2011) while respecting individuality;

- combating the ills of modernity such as loneliness, alienation, relativism of values, uncertainty of tomorrow (Duran et al. 2015).

In turn, Minica and France (2008) stress the importance of:

- promoting education, training and social support for the environment;

- protection and promotion of human health (increasing access to health facilities, especially in rural areas, control of communicable diseases, pollution risks and ecological hazards)

- the fight against poverty (through access to sustainable livelihoods for the poor, promotion of human development and integrated policy investment in human capital)

- sustainable demographic development, especially in developing countries.

Population growth, improvement of confidence, living and working conditions, development of social interactions and relationships, as well as the fight against alienation, poverty, health promotion and education are the issues that are directly related to the growing problems of difficulties in satisfying basic human needs, such as physiological needs, safety, belonging, recognition and self-improvement (Maslow 1970). According to the authors of this article, the issue of satisfying the need for security, as a key need of every human being, deserves special attention.

The link between security and sustainable development is highlighted by Johnson emphasising the changes in the perception of both issues (Johnson 2015). Once treated as two separate research fields, today they are increasingly considered in the context of interconnectedness (Hallding, Nykvist et al. 2013; Söderbaum, Granit 
2014) driven by climate change, the spread of poverty and increasing consumption (Bierbaum et al. 2014; Steffen et al. 2004). When considering security in its ecological, economic, food, water, social and environmental dimensions, more and more interdependencies can be seen, including the link between, for example, social pathology and a sense of security. The inability to satisfy the need for security may lead to economic stagnation, increased levels of corruption and fuelling social tensions (Liljedahl et al. 2012), which makes it necessary for states to pay attention not only to security in the traditional dimension (understood as a state of absence of threat - potential conflict), but first and foremost in the social aspect, where the focus is on people and social groups - including the local community (Johnson 2015). "This broad framing of human security is also found in the UN's definition: the right of people to live in freedom and dignity, free from poverty and despair" (United Nations 2005). However, it is worth emphasising that the effects of actions in the field of sustainable development, as well as activities aimed at ensuring a sense of security (in its various dimensions) are perceptible in the long-term perspective, which requires the adoption and observance of the adopted principles, the implementation of which will allow the achievement of both objectives, of course, with the making of certain expenditures and efforts. These actions should be taken not only on an international, European or national scale, but above all on a local scale, emphasising the importance of small communities, often culturally, geographically, and sometimes also religiously, economically, educationally and in terms of competence. Considering the political, economic and social factors that shape the environment necessary for the development of the concept of sustainable development and determine a sense of security, including a dynamic analysis of the context will enable the creation of conditions for achieving sustainable development and ensuring a sense of security (Johnson 2015).

\section{Local community and sense of security}

A local community can be defined as a group of people living in a common territory. Proximity to the place of residence determines the formation of social ties built on the basis of common problems and interests. An additional binding element is the cultural and often religious community which translates into the emergence of social standards, customs and traditions. The communities created in this way simultaneously build cultural distinctiveness constituting the basis for identification or rejection from the community. Understanding and observance of standards and customs, and not only living in a given territory, becomes the basis for assimilation of an individual into the society. Taking into account the above way of considering local communities, at least three ways of analysing the indicated communities can be indicated (Figure 1):

- spatial approach in which the territory in which a given community resides is analysed, including the specificity of this space in terms of urban planning, number and diversity of employers and public entities providing social services;

- a social approach that focuses on social interactions and bonds, the reasons for their formation and durability, the diversity of legal, religious, moral and customary standards that form the basis of group cohesion;

- psychological approach that emphasises the importance of the sense of belonging manifested in the attitude of local patriotism and the sense of security (analysed in various dimensions: individual and local) (Szacka 2003: 229).

Considering local communities in the indicated dimensions is undoubtedly related to the need to take into account the activities of a number of entities, including state institutions such as the police and municipal guards, whose activities are aimed at eliminating behaviour contrary to the established legal order and social standards. The group of institutions important in terms of ensuring the sense of security also includes labour offices and social welfare centres. 


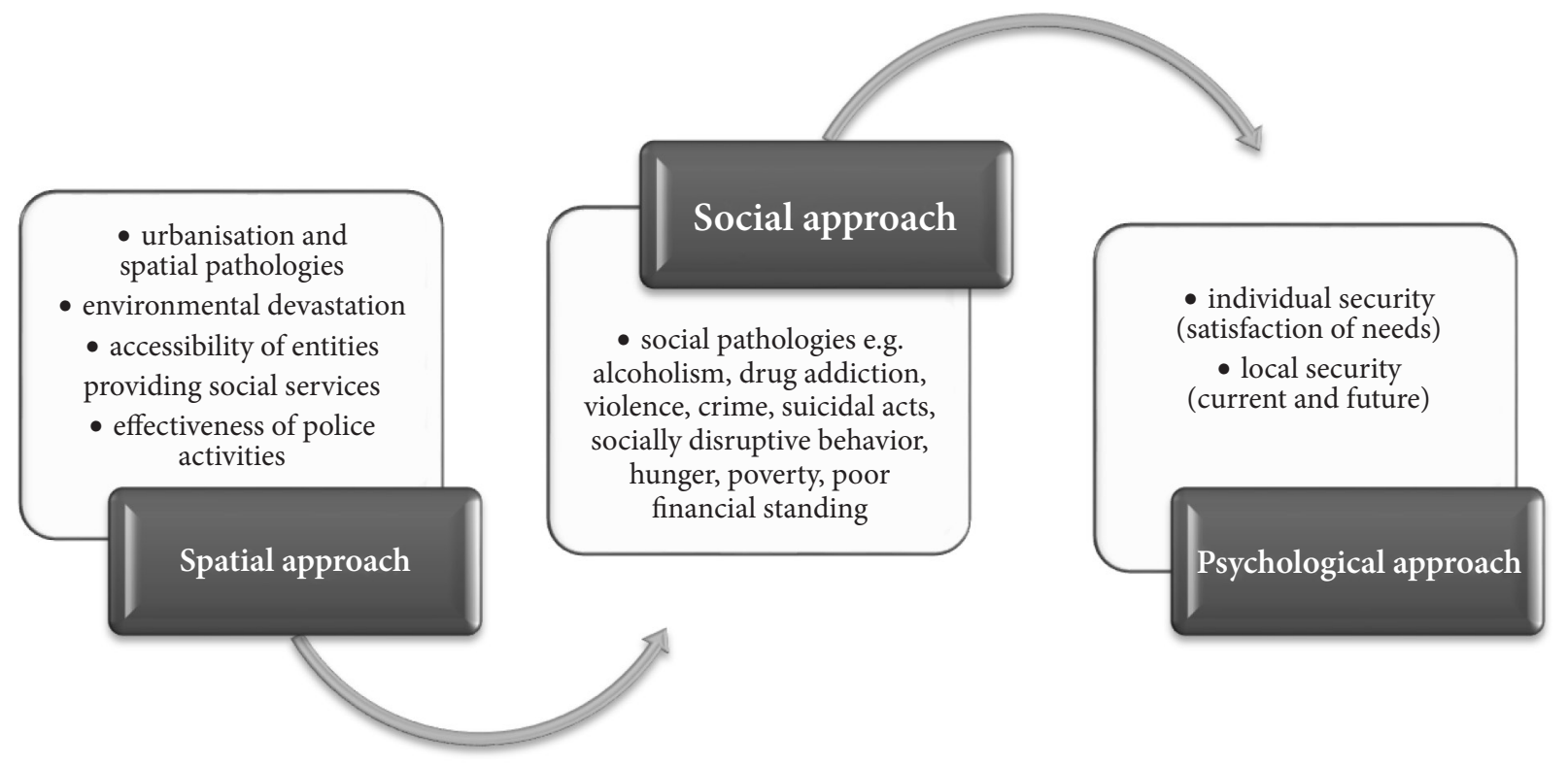

Figure 1. Approaches to community analysis

Source: own research based on Szacka (2003)

Actions aimed at building cohesion at the local and regional level are part of the priority actions of the European Union, because, in line with art. 3: "The Union (...) It shall work for the sustainable development of Europe based on balanced economic growth and price stability, a highly competitive social market economy, aiming at full employment and social progress, and a high level of protection and improvement of the quality of the environment. It shall promote scientific and technological advance. It shall combat social exclusion and discrimination, and shall promote social justice and protection, equality between women and men, solidarity between generations and protection of the rights of the child. It shall promote economic, social, and territorial cohesion, and solidarity among Member States. It shall respect its rich cultural and linguistic diversity, and shall ensure that Europe's cultural heritage is safeguarded and enhanced" (art. 3, The Treaty on European Union and the Treaty on the Functioning of the European Union).

Analysing the local community, the so-called local identity, which is a variety of social identity, created in a given territory and referring to its key attributes, deserves attention. The association of local culture with a shaped axiological system further strengthens the identity. Local identity can be considered within the framework of its particular dimensions, analysing, among others: psychological, sociological, economic, political, historical, anthropological and ethnographic, geographical, urban-architectural, world-view and ecological dimensions (Szczepański, Śliz 2011: 12-13). Local identity is also characterised by the level of social trust, which results from the analysis of the indicated identity dimensions. Low (...) "level of trust undermines social relations, arouses resentment, fear, causes that people do not want to get involved in any social relations, associations, are passive and do not take initiatives. Various defensive attitudes appear: negative stereotypes, aversion, xenophobia, crime is on the rise, etc." (Sztompka 2007: 308). This is confirmed by Mamzer according to whom: "In the social reality of the 21 st century, local communities in Poland face numerous challenges, and among them lies above all the challenge of reconciling the interests of different stakeholders, which is particularly difficult due to the low level of trust Poles have in each other" (Mamzer 2018: 33).

The extent of community involvement in sustainable development activities, not only globally but especially locally, is largely determined by the level of social awareness shaped in the educational and family environment. "Community involvement can be defined as the magnitude to which the residents are involved in the daily activities within the communities that they live in" (Lee 2013). However, given the globalisation tendencies towards community unification, activating local communities and supporting them (...) "can 
be a real antidote to the growing anomie and sense of loss" (Mamzer 2018: 35). Such activity, however, as Rivera et al. emphasise: “(...) is a long-standing challenge that becomes much harder when it involves multisector actors from businesses, environmentalists, governments, and local communities" (Rivera et al. 2017: 629-630).

Nevertheless, the issue of the influence of the sense of security of individuals, which on the one hand increases or decreases the level of involvement, and on the other hand is the result of the subjective assessment of the conditions of functioning and opportunities for development of a given individual, is not insignificant. The level of security of an individual, as well as of the whole local community, is undoubtedly influenced by social pathologies, and more precisely by the scale of their occurrence and their social consequences. Social pathologies pose a threat to safety because they disturb the social balance.

\section{Essence and types of social pathologies}

Social pathologies can be defined "as the social phenomena of individuals and groups displaying behaviour and social institutions functioning in contradiction with the values and principles accepted by a given society (SJP PWN), or as a specific state of attitudes, behaviours, and life situations, (...) which are detrimental to historically conditioned progress and cause negative consequences for the comprehensive development of an individual, a group or the whole society, and which consist in non-compliance with binding legal regulations, moral, moral and cultural standards, and in the rejection or disrespect of values that are objectively consistent with the interests of an individual and all the citizens at a given stage of the country's development" (Lipka 1977:14).

Social pathologies are often defined as dysfunctions of the social organism, which means that we can distinguish between individual pathologies (when individuals are the carriers and transmitters of negative features and behaviours) and pathologies of organised life (when an individual is the main object of negative influences of social structures, interpersonal relations) (SJP PWN).

The issue of social pathologies is considered using at least two approaches (Laitinen, Särkelä 2018). In the first, pathologies are seen as a term encompassing all socially criticised phenomena. Terms such as social evils, or social wrongs resulting from, among others, inappropriate distribution of wealth, influence of worldviews, invisibility of some individuals, and their problems are used as synonyms for social pathologies. In the second approach, on the other hand, pathologies are treated as phenomena with a similar structure and anti-naturalistic character. So-called second-order disorders, unlike the first-order phenomena, are not natural. As Laitinen, Särkelä highlight social pathologies can be linked to the following phenomena: oppression, domination or misrecognition taking place in the social world (2018).

Treating social pathologies as phenomena that do not have a natural character, referred to as social evil, allows the group of these phenomena to include, among others: alcoholism, drug addiction, violence and aggression, poor financial standing, unemployment, crime, intolerance, environmental neglect, nuisance behaviour, and pathologies concerning urbanisation and residential space (Pospieszył 2008). Definitions of selected social pathologies are presented in Table 1 . 
Table 1. Social pathologies - definitions

\begin{tabular}{|c|c|}
\hline Social pathology & Definition \\
\hline Alcoholism & $\begin{array}{l}\text { "any drinking of alcoholic beverages that goes beyond the measure of traditional, customary } \\
\text { consumption or beyond the framework of customary, social drinking accepted in the whole } \\
\text { community, regardless of the etiological factors that lead to such behaviour, and regardless of the } \\
\text { extent to which these etiological factors depend on heredity and acquired physiopathological and } \\
\text { metabolic influences" (WHO, } 1951 \text { after: Kulisiewicz 1984: 5). }\end{array}$ \\
\hline Drug addiction & $\begin{array}{l}\text { "permanent or periodical use for non-medical purposes of narcotic drugs, psychotropic substances, } \\
\text { substitutes or new psychoactive substances, as a result of which dependence on them may arise or } \\
\text { have arisen" (Act, 2005, art. } 4 \text { item 11). }\end{array}$ \\
\hline Aggression & $\begin{array}{l}\text { "Intentional behaviour directed at hurting or causing pain. It can be both verbal and physical in } \\
\text { nature (Aronson 1997: 497). }\end{array}$ \\
\hline Violence & $\begin{array}{l}\text { "Any non-accidental act that takes advantage of the perpetrator's superiority, that harms the } \\
\text { individual's personal freedom, that contributes to physical or psychological harm and that goes } \\
\text { beyond the social standards of interaction, or any act of torment and cruelty" (Pospieszył 2008: 57). }\end{array}$ \\
\hline Poverty & $\begin{array}{l}\text { "is a restriction of life choices and opportunities, a violation of human dignity. It means not being } \\
\text { able to participate effectively in society. It also means not having enough food and clothing for } \\
\text { the family, not being able to go to school or get health care, not having access to land that can } \\
\text { be farmed or work to earn a living, not having access to credit. Poverty also means vulnerability, } \\
\text { powerlessness and exclusion of individuals, families and communities. It implies vulnerability } \\
\text { to violence and often involves living in precarious conditions without access to clean water and } \\
\text { sanitation" (UN 1998). }\end{array}$ \\
\hline Unemployment & $\begin{array}{l}\text { A situation in which those able and willing to work cannot find work. Being unemployed for long } \\
\text { periods of time has a negative impact on wellbeing, translates into an inability to purchase basic } \\
\text { goods and therefore an inability to meet basic needs (Dodd, Nyabvudzi 2014). }\end{array}$ \\
\hline Crime & $\begin{array}{l}\text { "A set of acts prohibited by law under penalty of punishment, which acts are committed within a } \\
\text { given territorial unit and at a given time. Crime can be considered in terms of its extent, intensity, } \\
\text { structure and dynamics" (Chmielewski, Woźniak 2005: 241). }\end{array}$ \\
\hline
\end{tabular}

Social pathology also includes the phenomenon of discrimination on the basis of, for example, gender and age (particularly evident in the employment process), any neglect of the environment leading to its devastation, as well as socially disruptive behaviour such as noise. Social pathologies may also include pathologies related to urbanisation and residential space resulting in limited accessibility for e.g. disabled persons.

The indicated social pathologies are undoubtedly connected to the sense of security of local communities, as well as their very occurrence is connected to the lack of sustainable development. As Nakabashi (2008) points out: poverty reduction is a key action within the concept of sustainable development, and poverty itself represents a huge challenge for policy makers. An important action aimed at poverty reduction is the involvement of local communities. "Poverty reduction initiatives that use the community as the main channel for mobilization and involvement must focus on the dynamics and the specificity of context as different kinds of participation imply significantly different levels of engagement. Community participation has a huge potential to engage citizens, including poor citizens, in debates about public policy from local to national level and in a range of sectors" (Osei-Kufuor, Koomson 2014: 1626).

Caring for the development of communities increases the sense of security, while also allowing for the reduction of unemployment - another social pathology, as: "An increase in unemployment leads to reduced growth, since unemployment reduces aggregate income, savings and capital accumulation” (Bräuninger 2004: 12). It can therefore be concluded that the indicated social pathologies have the character of related phenomena, partly self-propelled. Undertaking activities aimed at the implementation of the concept of sustainable development allows not only for the elimination of the indicated pathologies, but also increases social awareness, leading to development. "As the economic growth is a main dimension of the sustainability, it accelerates the sustainability process. A rich country is not only strong in economy, but also it is likely to be socially advanced and environmentally clean; it is due to the fact that the rich economies can afford to finance the social and environmental institutions/projects" (Nasrollahi et al. 2020: 1107). 
In conclusion, the awareness of social pathologies occurring in a given local community allows for a more complete understanding of the spectrum of social behaviour, which translates into a sense of security of both the individual and the entire local community.

\section{Analysis of research results}

For the purposes of this article, a survey was carried out using the method of diagnostic poll, where the technique was surveying, and the tool was a questionnaire. The study was carried out within the framework of the scientific research work entitled: Attributes of security administration of security management bodies in the perspective of local communities. The study involved 600 people, the criterion adopted for the selection of respondents was their place of residence. In relation to research limitations respondents were selected from 6 cities (100 respondents from each city), broken down by: cities with a military unit - Siedlce (Mazowieckie), Zamość (Podkarpackie), Zgierz (Łódzkie); cities without a military unit - Ostrów Wielkopolski (Wielkopolska), Włocławek (Kujawsko-Pomorskie), Piła (Wielkopolska). In cities without a military unit, where the 2019 residents were surveyed, the military had previously been stationed. Chosen respondents group was selected intentionally and because of that it doesn't meet representation requirements. It follows, that achieved empirical data can't be related to the questioned population as a whole. The survey was conducted in November and December 2019. And so in Chart 1 presents empirical data showing the place of residence of the respondents.

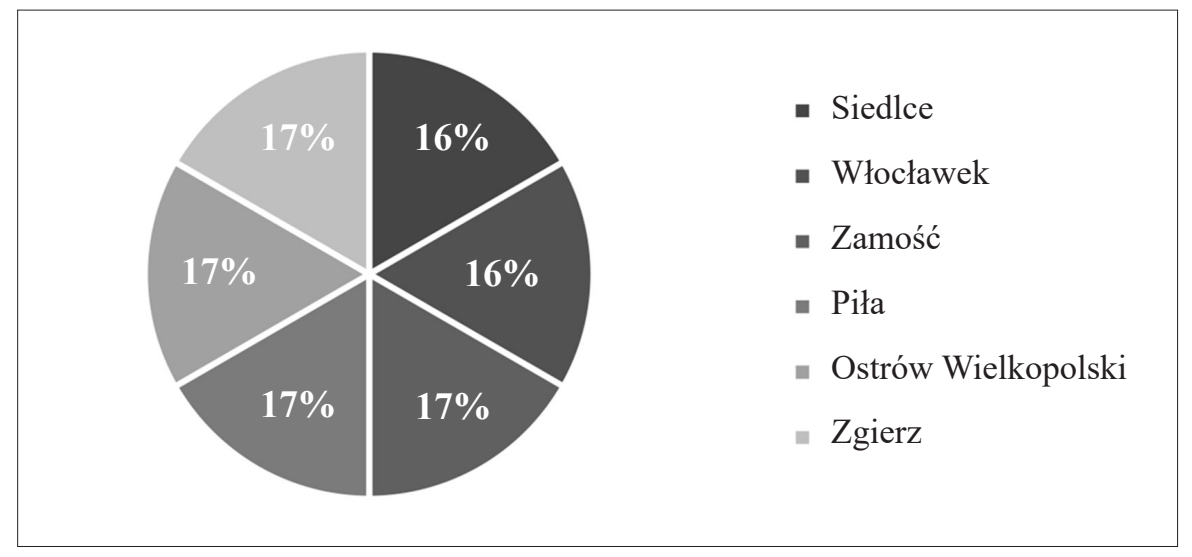

Chart 1. Respondents' place of residence

Source: own study.

Respondents who took part in the research were selected from the following towns: Siedlce (16\%), Włocławek (16\%), Zamość (17\%), Piła (17\%), Ostrów Wielkopolski (17\%), Zgierz (17\%). directly related to how the local community perceives the impact of social pathologies on their functioning.

The key research problem that had to be solved in the context of the development of this article was formulated as the following question: What is the impact of the presence of underlying social pathologies on the sense of security in the local community? The empirical data collected to answer the above research problem were presented in an aggregated form on charts illustrating the examined social phenomena, such as: alcoholism, drug addiction, violence and aggression, poor financial standing, poverty, unemployment and crime. As regards alcoholism and its influence on the sense of security in the local community, the summary results are presented in Chart 2. 


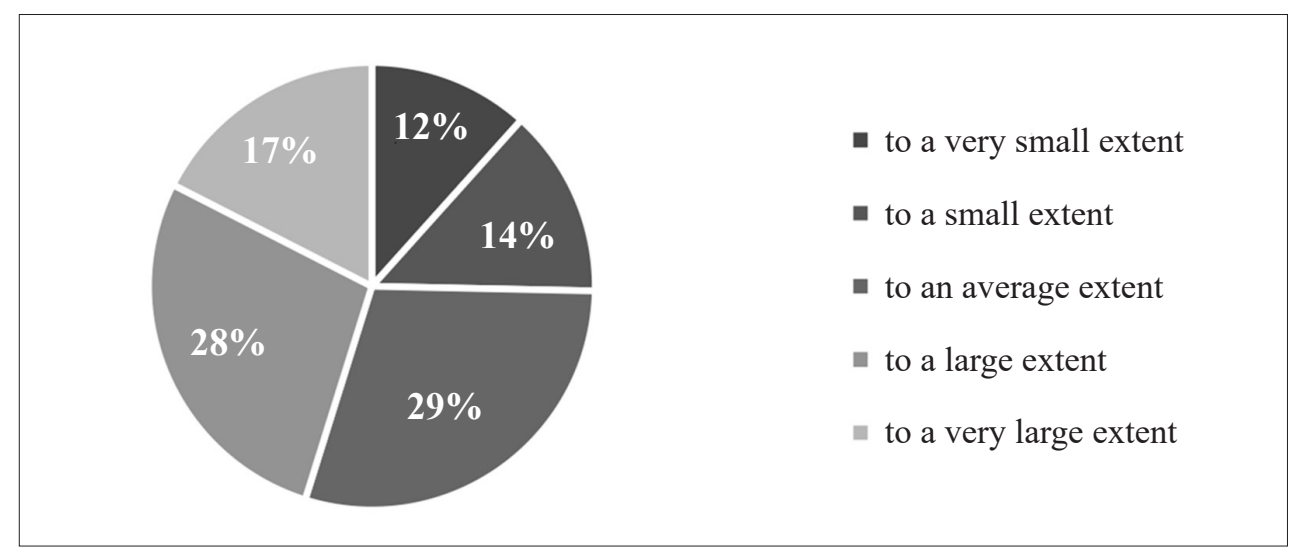

Chart 2. Alcoholism in the surveyed local community

Source: own study.

The obtained empirical results are the basis for stating that 177 respondents (29\%) recognised that this pathology affects their sense of security to an average degree, 166 respondents $(28 \%)$ indicated that the examined pathology affects security to a high degree. Whereas 105 respondents $(17 \%)$ believed that it is a phenomenon that has a very high impact on their sense of security, only 82 people (14\%) stated that the examined factor is small, and 78 respondents $(12 \%)$ believed that the impact of alcoholism on the security of the local community is very small.

The above analysis leads to the conclusion that the research group, i.e. the local community perceives the issues of alcoholism as having an average impact on their sense of security, but also a significant proportion of the surveyed persons indicate that this pathology affects them to a great extent.

The second pathology which was examined in the respondents' environment was the phenomenon of drug addiction. Summary responses are presented in Chart 3 below.

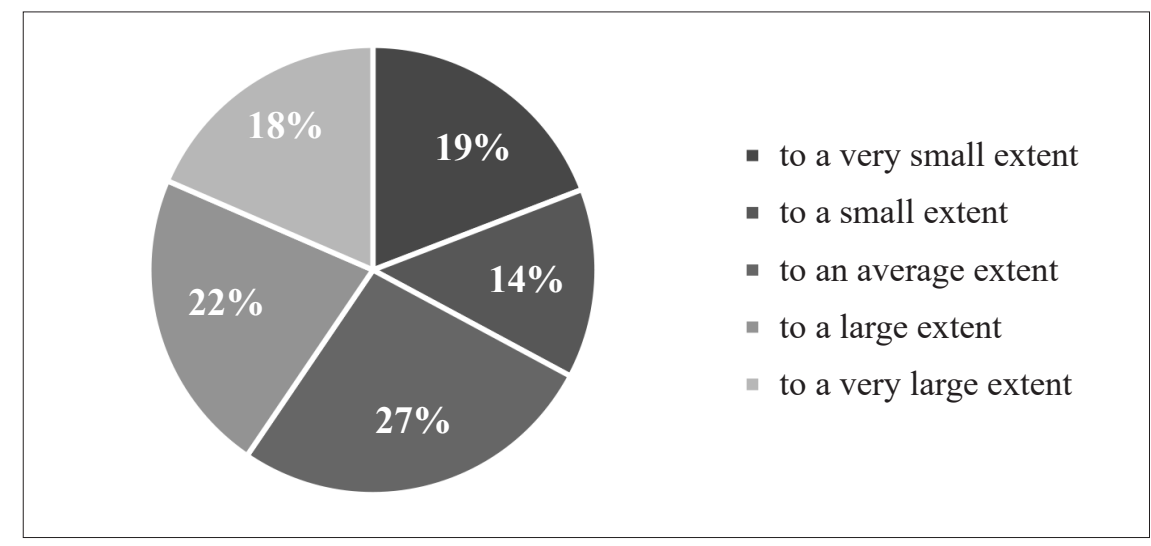

Chart 3. Drug addiction in the surveyed local community

Source: own study.

With respect to the phenomenon of drug addiction, the answers of the survey respondents were distributed as follows: 160 people (27\%) considered that the pathology under study affects their sense of security in the local community to an average degree, while 132 people (22\%) indicated that drug addiction affects their sense of security to a high degree. As a result of the research process, it was found that 115 people $(19 \%)$ felt that drug addiction affected their sense of safety to a very small extent, while 111 respondents (18\%) felt that it was a pathology that affected their sense of safety to a large extent. Out of the total research group, 82 respondents (19\%) perceive a small impact of the phenomenon on the sense of security of the local community. 
Summarising the collected research results, one may conclude that drug abuse issues in the surveyed community are perceived as having an average impact on the local environment, but also for a considerable group of respondents as having a large impact on them.

Then, among the respondents of the questionnaire, the impact of violence and aggression on the safety of the local community was determined. The aggregated responses are presented in Chart 4 below.

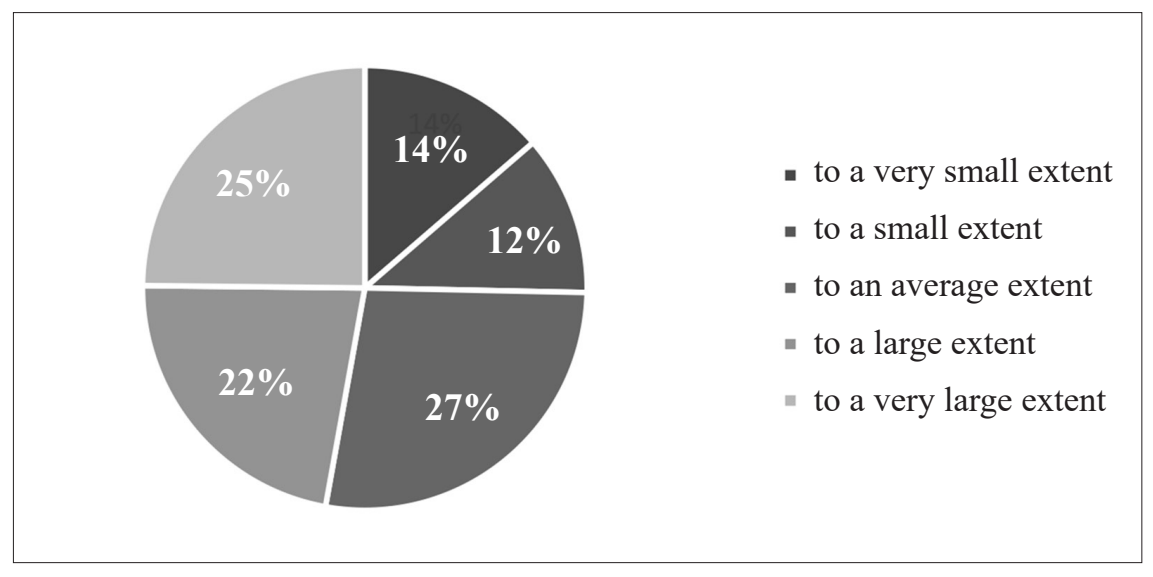

Chart 4. The phenomenon of violence and aggression in the surveyed local community

Source: own study.

As a result of the survey, 165 respondents $(27 \%)$ said that this phenomenon influences their sense of security in the local community to an average degree, while 149 people $(25 \%)$ said that this phenomenon influences their sense of security to a large degree. On the basis of the collected results it was established that 134 respondents $(22 \%)$ stated that violence and aggression have a great impact on their sense of security, while 82 respondents $(14 \%)$ indicated that this phenomenon influences their sense of security to a very small extent, and 70 respondents $(12 \%)$ stated that it influences it to a small extent.

The above results allow to draw the conclusion that violence and aggression in the opinion of the respondents is a pathology that affects their sense of security to an average or high degree.

Another pathology surveyed among the respondents was poor financial standing. The respondents' answers in a collective form are presented in Chart 5 below.

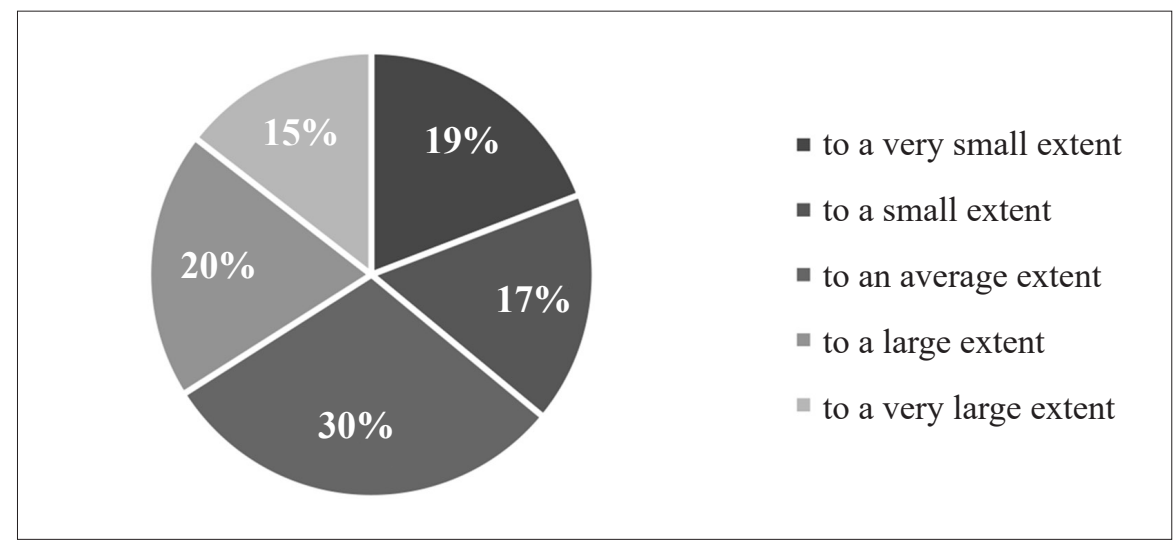

Chart 5. The phenomenon of poor financial standing in the surveyed local community

Source: own study. 
The knowledge gathered during the research process proves that in the opinion of 180 respondents (30\%) poor financial standing influences their sense of security to an average degree, while for 117 respondents (20\%) it is a phenomenon that influences their sense of security to a large degree. Out of the total number of 600 respondents as many as 115 people (19\%) think that the impact of poor financial standing on their sense of security is very small, while 101 respondents (17\%) perceive a small impact of poor financials standing on their sense of security in the local community. Of the total number of respondents, 87 people $(15 \%)$ indicated that the pathology under study affects their sense of security to a great extent.

Another pathology that was surveyed in the context of community safety was poverty. The responses in the form of aggregated results are presented in Chart 6 below.

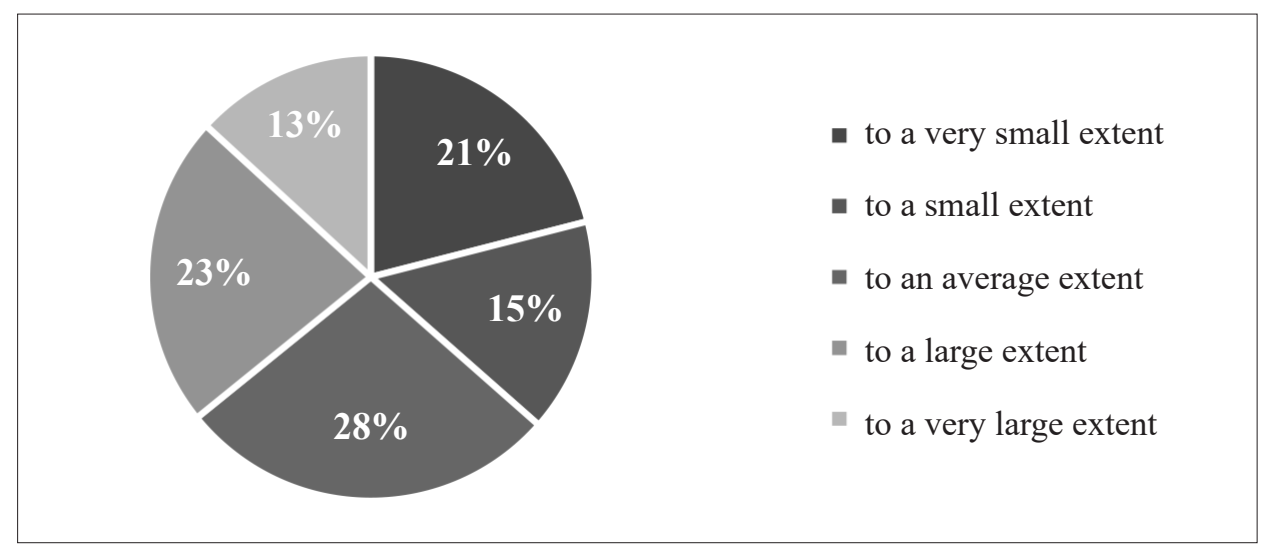

Chart 6. The phenomenon of poverty in the surveyed local community

Source: own study.

In relation to the pathology of poverty, respondents indicated that 166 people (28\%) felt that poverty had an average impact on their sense of security. In contrast, for 136 respondents $(23 \%)$, poverty affects their sense of security to a great extent. For 126 respondents (21\%), poverty has very little effect on the examined variable, and for 96 people (15\%), it determines the level of security to a small extent. Whereas for 79 respondents (13\%), poverty affects their sense of security to a great extent.

Summing up, it can be concluded that poverty as a category of pathology examined in terms of community safety is perceived as having an average or high impact on community functioning. The next (sixth) pathology surveyed among the respondents was unemployment. The aggregated responses are presented graphically in Chart 7 below.

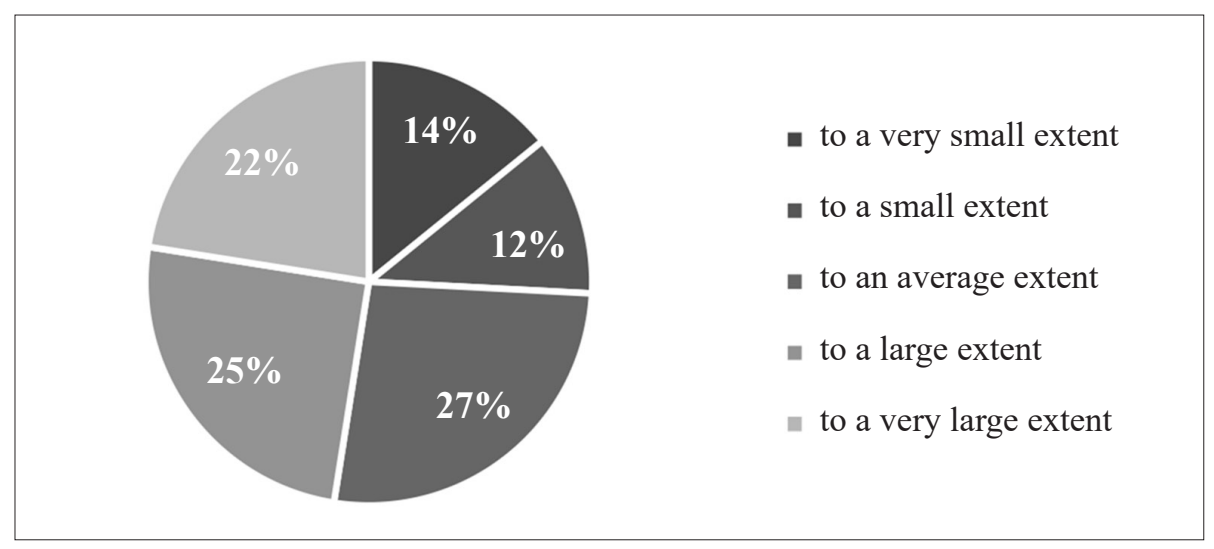

Chart 7. The phenomenon of unemployment in the surveyed local community

Source: own study. 
In the context of social pathology like unemployment, the respondents' answers were characterised by a low level of variance. As a result of the research it was found that 160 persons $(27 \%)$ stated that the examined pathology factor influences their sense of safety within the local community to an average degree, while 150 persons $(25 \%)$ indicated that unemployment influences their sense of safety to a large degree, 135 respondents $(22 \%)$ stated that it has a very big influence, and for 85 persons $(14 \%)$ it has a small influence on their sense of safety. Only for 70 respondents (12\%) the impact of unemployment on their sense of security is small.

The survey shows that the issue of unemployment is for the surveyed group an element that affects their sense of security to an average or high degree.

Crime was the seventh pathology that was examined in the group of respondents. The responses gathered in a graphical form are presented in Chart 8 below.

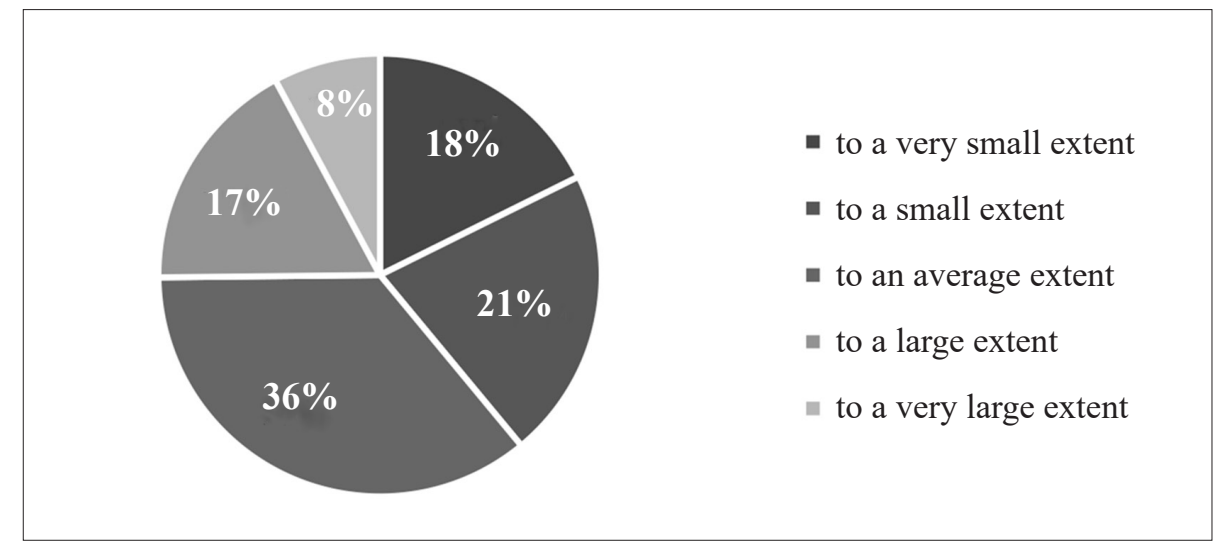

Chart 8. Crime in the surveyed local community

Source: own study.

In relation to crime, the respondents' answers were as follows: 215 people (36\%) felt that the impact on their sense of security was average. For 128 respondents (21\%) crime has a low impact, and for 106 respondents $(18 \%)$ it has a very low impact. Meanwhile, for 104 people $(17 \%)$, the impact of crime on their sense of community safety was high, while for 47 respondents ( $8 \%$ ) very high.

In conclusion, the results of the research show that the issue of crime is perceived as having an average or low impact, which may be related to the presence of military units in the areas concerned, which can significantly contribute to a sense of security in relation to the phenomenon of crime.

Calculations related to Pearson correlation coefficient are summarised in the table 2 . below. The independent variable indicated in this table is abode of respondents, dependent variables are understood as social pathologies shown in diagrams above, i.e. alcohol abuse, drug addiction, aggression and violence, unemployment, poverty and crime.

Table 2. Correlations between the abode of respondents and social pathologies

\begin{tabular}{|c|c|}
\hline Social pathology & Pearson correlation coefficient \\
\hline Alcohol abuse & $-0,358$ \\
\hline Drug addiction & $-0,404$ \\
\hline Aggression and violence & $-0,393$ \\
\hline Distress & $-0,439$ \\
\hline Poverty & $-0,460$ \\
\hline Unemployment & $-0,467$ \\
\hline Crime & $-0,431$ \\
\hline
\end{tabular}


As it appears from empirical data presented in table 2. it can be stated, that power of the connection between independent variable and independents variables, qualified to study correlations coefficient according to Pearson method is average and negative with reference to all social pathologies. In this connexion we can state, that respondents don't connect abode with occurrence of respective social pathologies.

For the needs of the present elaboration in next part of the sense of security studies, as independent variable abode of respondents was indicated. Mentioned dependent variables for correlations tests according to Pearson correlation coefficient are:

- communication with services like: police, city guard, district constable, social assistance and fire-guard,

- activities having an effect on sense of security like: preventive activities, information campaigns, successful services interventions, public accessibility to services, exclusion of persons under the stress of pathologies from local community.

Results of studies concerning testing of connection power between variables from the point of view of communication with respective services are indicated in table 3.

Table 3. Correlations between the communication with services and sense of security in local society

\begin{tabular}{|c|c|}
\hline Communication with services & Pearson correlation coefficient \\
\hline Police & 0,125 \\
\hline City guard & $-0,094$ \\
\hline District constable & $-0,025$ \\
\hline Social assistance & $-0,158$ \\
\hline Fire-guard & 0,108 \\
\hline
\end{tabular}

Regarding obtained results of testing Pearson correlation coefficient, it amounts to 0,125 and it is weak plus correlation, same in case of fire-guard - weak plus correlation amounts to 0,108 . It manifests respondent's positive opinion as for communication with indicated services in their abode.

In other cases:

- for city guard correlation coefficient amounts to $-0,094$ and for district constable it amounts to $-0,025$. In both cases coefficients confirms hardly perceptible negative correlation, so drawing a conclusion that respondents are not in sufficient touch with above mentioned services in their abode is legitimated,

- for social assistance correlation coefficient $(-0,158)$ is also weak negative, so it is easy to conclude that communication with this service is similar, like in cases of district constable and city guard.

On the other hand, data regarding power of the unit between variables, shown in table 4., notice bearing of influence of preventive activities on sense of security in local communities.

Table 4. Activities, bearing of influence on sense of security in local communities - correlations

\begin{tabular}{|c|c|}
\hline Activities in local community & Pearson correlation coefficient \\
\hline Preventive activities & 0,123 \\
\hline Information campaigns & 0,062 \\
\hline Successful services interventions & 0,213 \\
\hline Public accessibility to services & 0,150 \\
\hline $\begin{array}{l}\text { Exclusion of persons under the stress } \\
\text { of pathologies from local community }\end{array}$ & $-0,036$ \\
\hline
\end{tabular}


In connection with the obtained empirical data can be mentioned that activities undertaken in local communities are perceived as positive in cases of :

- preventive activities with correlation coefficient amounting to 0,123 (weak plus correlation);

- information campaigns with correlation coefficient amounting to 0,062 (weak, but positive correlation);

- successful services interventions with correlation coefficient amounting to 0,213 (weak plus correlation);

- public accessibility to services with correlation coefficient amounting to 0,150 (weak plus correlation also).

Basing on above results can be concluded that activities realized in respondents abode are estimated by them positively and that they perceives connection between activities leaded in local community and their sense of security. On the other hand, regarding question of exclusion from local community persons under the stress of social pathologies like alcohol abuse, drug addiction, violence, aggression, poverty, distress, unemployment, criminality, correlation coefficient amounts to minus 0,036 and should be understood as negative weak correlation. Having it in mind it's easy to conclude that, according to the opinion of respondents, they don't perceive so strong connections between this factor and their sense of security in local communities, so they don't see the necessity of exclusion/isolation of persons under the stress of social pathologies from local community.

Summarising the research results included in this article, it can be pointed out that the respondents have to deal with the following social pathologies in their local community: alcoholism, drug addiction, violence and aggression, poor financial standing, poverty, unemployment and crime. The respondents perceive differentiated influence of the examined pathologies on their feeling of safety connected with functioning in the local community.

With regard to alcoholism, drug addiction, violence and aggression, poor financial standing, poverty and unemployment, respondents indicated that it influences their sense of security to an average or high degree. On this basis, it may be concluded that the social pathologies taken into account in the research process are a significant factor determining safety in the local community. With respect to the crime phenomenon, the results indicate that the examined indicator has an average impact or even a small impact on the respondents' sense of security in the local community. This may be directly related to the fact that military units are deployed in the areas covered by the survey, which is usually associated with a general increase in the sense of security especially in relation to the phenomenon of crime. The results of the obtained research provide a basis for the conclusion that the respondents are aware of the existence of social pathologies and perceive their impact on the sense of security.

It can be also concluded, that communication with various services taking care of and responsible for the security of residents in local communities is rather poor and only two structures were estimated positively by respondents from the point of view of communication. However, activities realised in nearest neighbourhood of respondents were for them important and essential. In opinion of most of the respondents above mentioned activities affected positively on their sense of security in their abode communities.

\section{Conclusions}

The aim of this article was to answer the research problem formulated in the form of the following question: What is the influence of the occurrence of particular social pathologies on the sense of security in the local community?

The empirical data obtained and presented here allow to answer the research problem posed. Firstly, the analysis of the research results shows that among the 600 respondents from various cities in Poland, the feeling for the influence of social pathologies on the sense of security of the local community is perceived as average or high.

Such a diversity of answers may result from the fact that the inhabitants of the cities selected for the study are to a large extent professional soldiers, whose rhythm of work and certain habits and values they follow determine 
the safety in the local community. Moreover, they are a kind of closed social groups, where the inhabitants are known and in a natural way shape the level of security, which necessarily translates into the perception of the social pathologies discussed in the article as less threatening and having less impact on their sense of security.

Please pay your attention also to additional context shown in this analysis, i.e. opinion concerning communication with services, having possibility of influence over the sense of security in local community. In opinion of respondents police and fire- guard are decidedly those services, which influences over their sense of security positively. Opinion concerning influence of activities realised to prevent generally understanding social pathologies like alcohol abuse, drug addiction, violence, aggression, distress, poverty, unemployment, crime was an important part of studies also. Respondents indicated in this case as well that prevent activities, information campaigns, services interventions and accessibility to services are factors, influencing on sense of security in occupied by them local communities.

The authors of the article are aware that the content presented in the article constitutes only a selected part of the research reality and the obtained research results may become a basis for more extensive research activities.

\section{Acknowledgement}

The research was financed within the framework of statutory activities specified in the Task and Financial Plan of scientific activity of the War Studies University, no. II.2.5 no. 254.

\section{References}

Aronosn, E. (1997). Człowiek - istota społeczna (The Social Animal). WN PWN. Warsaw

Bierbaum, R., Stocking, M., Bouwman, H., Cowie, A., Diaz, S., et al. (2014). Delivering Global Environmental Benefits for Sustainable Development. Report to the 5th GEF Assembly. Mexico. Global Environment Facility, Washington, DC. https://assembly.thegef.org/ publications/delivering-global-environmental-benefits-sustainable-development-report-5th-gef

Bräuninger, M. (2004). Social Security, Unemployment and Growth. HWWA Discussion Paper 266

Broman, G.I., Robèrt, K-H. (2017). A framework for strategic sustainable development. Journal of Cleaner Production, 140, 17-31. DOI: $10.1016 /$ j.jclepro.2015.10.121

Chmielewski, H., Woźniak, W. (2005). Organiczne i afektywne uwarunkowania przestepczości (Organic and affective determinants of crime). Łódzkie Studia Teologiczne. 14, 241-248

Ciegis, R., Ramanauskiene, J., Martinkus, B. (2009). The concept of sustainable development and its use for sustainability scenarios. Eng. Econ. 62, ISSN 1392-2785

Cotter, B., Hannan, K., (1999). Our Community, Our Future: A Guide to Local Agenda 21, Commonwealth of Australia, Canberra

Dempsey, N., Bramley, G., Power, S., \& Brown, C. (2011). The social dimension of sustainable development: Defining urban social sustainability. Sustainable Development, 19(5), 289-300

Dodd, N. M., Nyabvudzi, T. G. (2014). Unemployment, Living Wages and Food Security in Alice, Eastern Cape, South Africa. Journal of Human Ecology, 47(2),117-123. DOI: 10.1080/09709274.2014.11906744

Duran, D.Cr., Gogan, L.M., Artene, A., Duran, V. (2015). The Components of Sustainable Development - A Possible Approach. Procedia Economics and Finance 26, 806-811. DOI: 10.1016/S2212-5671(15)00849-7

Edelman (2015). Edelman Trust Barometer - Global Results. http://www.edelman.com/2015-edelman-trust-barometer-2/trust-and-innovation-edelman-trust-barometer/global-results

Hallding, K., Nykvist, B., Persson, Å. (2013). The new geopolitics of environmental constraints, changing ecosystems and resources competition. In: Strategic Yearbook 2012-2013: The Emerging Global Security Environment. Huldt, B., Ries, T., Sivonen, P., and Huldt, C., (eds.). National Defence College, Stockholm

Johnson, O. (2015). Integrating sustainable development and security: An analytical approach with examples from the Middle East and North Africa, the Arctic and Central Asia. Stockholm Environment Institute, Working Paper (14) 
Klarin, T. (2018). The Concept of Sustainable Development: From its Beginning to the Contemporary Issues. Zagreb International Review of Economics and Business, 21(1), 67-94. DOI: 10.2478/zireb-2018-0005

Kulisiewicz, T., (1984). Zespół uzależnienia alkoholowego (choroba alkoholowa). Rozpoznanie i leczenie (Alcohol dependence syndrome (alcoholism). Diagnosis and treatment). Społeczny Komitet Przeciwalkoholowy. Warsaw

Laitinen, A., Särkelä, A., (2018). Four Conceptions of Social Pathology. European Journal of Social Theory, 22(2). DOI: $10.1177 / 1368431018769593$

Lee, T. H. (2013). Influence Analysis of Community Resident Support for Sustainable Tourism Development. Tourism Management, $34,37-46$

Liljedahl, B., Waleij, A., Sandström, B., Simonsson, L. (2012). Medical and environmental intelligence in peace and crisis-management operations. In: Assessing and Restoring Natural Resources in Post-Conflict Peacebuilding

Jensen, D. and Lonergan, S., (eds.). Earthscan, London. https://www.researchgate.net/publication/265395680_Natural_resources_and_ post-conflict_assessment_remediation_restoration_and_reconstruction_Lessons_and_emerging_issues

Lipka, A. (1977). Zjawiska patologii społecznej wśród młodzieży (Phenomena of social pathology among adolescents). Wydawnictwo Naukowe PWN, Warsaw

Mamzer, H. (2018). Społeczność lokalna jako źródło poczucia bezpieczeństwa ontologicznego? (Local community as a source of ontological security?). In: Herudziński T., Swacha P., (eds.) Społeczności lokalne. Konteksty przemian i innowacje (Local communities. Contexts of change and innovations). Wydawnictwo SGGW, Warsaw

Maslow, A.H. (1970). Motivation and Personality. Harper and Row. New York

Minica, M., Franţ, F. (2008). The dimensions of durable development. Annals of the University of Craiova Economic Science XXXVI7, 34323439

Munasinghe, M. (1994). Sustainomics: A Transdisciplinary Framework for Sustainable Development. Keynote Paper, Proceedings of the 50th Anniversary Sessions of the Sri Lanka Association for the Advance of Science (SLAAS), Colombo, 56-65

Nakabashi, L. (2018). Poverty and economic development: Evidence for the Brazilian states. EconomiA, 19(3), 445-458. DOI: 10.1016/j.econ.2018.11.002

Nasrollahi, Z., Hashemi, M-s, Bameri, S., Mohamad, T.V. (2020). Environmental pollution, economic growth, population, industrialization, and technology in weak and strong sustainability: using STIRPAT model. Environment, Development and Sustainability: A Multidisciplinary Approach to the Theory and Practice of Sustainable Development. Vol 22, issue 2, No 25, 1105-1122. DOI: 10.1007/ s10668-018-0237-5

National Research Council. Policy Division. Board on Sustainable Development. Our Common Journey: A Transition toward Sustainability (1999). Washington, DC: National Academy Press, 22

Osei-Kufuor, P., Koomson, F., (2014). Reducing poverty through community participation: The case of the National Poverty Reduction Program in the Dangme-West district of Ghana. International Journal of Development and Sustainability, 3(8), 1611-1628. Article ID: IJDS14011001

Parson, E.A., Haas P.M. (1992). A Summary of the Major Documents Signed at the Earth Summit and the Global Forum. Environment, October, $12-18$

Pospieszył, I. (2008). Patologie społeczne (Social pathologies). Wydawnictwo Naukowe PWN, Warsaw

Pospieszył, I. (2008). Przemoc $w$ rodzinie (Violence in the family). In: Resocjalizacja (Resocialization). t. 2. (eds.) Urban B., Stanik J. M., Warsaw WN PWN

Rivera, J., Naranjo, M.A., Robalino, J., Alpizar, F., Blackman, A., (2017). Local Community Characteristics and Cooperation for Shared Green Reputation. Policy Studies Journal, 45(4), 613-632. DOI: 10.1111/psj.12156

Robert, K.W., Parris, T.M., Leiserowitz, A.A. (2005). What is Sustainable Development? Goals, Indicators, Values, and Practice. Environment: Science and Policy for Sustainable Development, 47(3), 8-21. DOI: 10.1080/00139157.2005.10524444

Shi, L., Han, L., Yang, F., Gao, L. (2019). The Evolution of Sustainable Development Theory: Types, Goals, and Research Prospects. Sustainability, 11(7158). DOI: 10.3390/su11247158 
Słownik Języka Polskiego PWN (PWN Polish Language Dictionary), https://encyklopedia.pwn.pl/haslo/patologie-spoleczne;3955029. html

Söderbaum, F., Granit, J., (2014). The Political Economy of Regionalism: The Relevance for International Waters and the Global Environment Facility. STAP Issues Paper. Global Environment Facility, Washington, DC. https://www.academia.edu/7015054/The_Political_Economy_of_Regionalism_The_Relevance_for_International_Waters_and_the_Global_Environmental_Facility

Statement of commitment for action to eradicate poverty adopted by Administrative Committee on Coordination. Economic and Social Council E/1998/73, https://www.unsceb.org/CEBPublicFiles/press/9818151e.pdf

Steffen, W. L., Sanderson, A., Tyson, P., Jäger, J., Matson, P., et al. (2004). Global Change and the Earth System: A Planet under Pressure. Global change - the IGBP series. Springer, Berlin and New York. http://www.igbp.net/download/18.1b8ae20512db692f 2a680007761/1376383137895/IGBP_ExecSummary_eng.pdf

Szacka, B. (2003). Wprowadzenie do socjologii (Introduction to sociology). Oficyna Naukowa, Warsaw

Szczepański, M., S., Śliz, A. (2011). Rewitalizacja i mobilizacja społeczna - zarys problematyki (Revitalization and social mobilization - an outline of the issues). In: Rewitalizacja społeczna - od aktywizacji do rozwoju lokalnego (Social revitalization - from activation to local development). (ed.) Łukowski, W., Wydawnictwo Naukowe Instytutu Technologii Eksploatacji - Państwowy Instytut Badawczy. Radom. ISBN: 978-83-7328-271-1

Sztompka, P. (2007). Zaufanie. Fundament społeczeństwa (Trust. The foundation of society). Znak. Kraków

The Johannesburg Declaration on Sustainable Development. 4 September 2002. http://un-documents.net/jburgdec.htm

The United Nations Conference on Environment and Development (UNCED). https://www.un.org/en/conferences/environment/rio1992

Consolidated versions of the Treaty on European Union and the Treaty on the Functioning of the European Union 2012/C 326/01. https://eur-lex.europa.eu/legal-content/EN/TXT/?uri=CELEX\%3A12012M\%2FTXT

United Nations (2005). 2005 World Summit Outcome. UN General Assembly Resolution A/RES/60/1. New York. http://www.assumptionjournal.au.edu/index.php/abacjournal/article/download/608/543

United Nations (2013). World Population Prospects: The 2012 Revision (No. ESA/P/WP.228). United Nations Act of 29 July 2005 o preventing drug addiction (Journal of Laws of 2019, item 852, as amended)

World Commission on Environment and Development (WCED). (1987). Our Common Future, New York: Oxford University Press

\section{About contributors:}

Dorota KUREK is an academic teacher, holds a doctoral degree in social sciences in the discipline of defence at the Faculty of Management and Command at the War Studies University, conducts classes for civilian students in the area of human resource management as well as leadership and employer branding. Research interests are related to HRM, leadership, employer branding.

ORCID ID: 0000-0002-2346-6108

Marlena NIEMIEC is an academic teacher, holds a doctoral degree in social sciences in the discipline of defence at the Faculty of Management and Command at the War Studies University, conducts classes for civilian students in the area of ethics, social pathologies, conflicts, and negotiations. Research interests are related to ethics, organizational and social pathologies as well as conflicts and negotiations.

ORCID ID: 0000-0001-6025-1862 